\title{
RUPKATHA JOURNAL
}

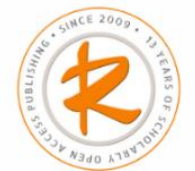

\begin{tabular}{|c|c|}
\hline \multicolumn{2}{|r|}{ About the Journal } \\
\hline Journal DOI & https://doi.org/10.21659/rupkatha \\
\hline Journal Home & www.rupkatha.com \\
\hline & Scopus $\searrow$ Web of Science: Emerging Sources Citation Index (ESCI) DOAJ \\
\hline Journal Metrics & CiteScore 2020: 0.2 | SJR 2020: 0.162 | SNIP 2020: 0.193 | JCI 2020: 0.50 \\
\hline \multicolumn{2}{|r|}{ About the Issue } \\
\hline Themed issue & $\begin{array}{l}\text { Volume 4, number 1, } 2022 \text { (January-March) | Contemporary East and } \\
\text { Southeast Asian Literary and Cultural Studies }\end{array}$ \\
\hline Guest Editors & Dr Jeremy de Chavez $\triangle$ \& Dr Zhang Yue, University of Macau, China \\
\hline Issue DOI & https://doi.org/10.21659/rupkatha.v14n1 \\
\hline TOC & https://rupkatha.com/v14n1.php $\square$ \\
\hline Peer Review & Under the responsibility of the Guest Editors \\
\hline \multicolumn{2}{|r|}{ About the Article } \\
\hline Title & Foreignized Translation of Onomatopoeia in The Last Lover \\
\hline Author/s & Minhui $\mathbf{X} \mathbf{u}^{*} \otimes \&$ Tingting Chen $\mid{ }^{*}$ Corresponding author \\
\hline Affiliation & Faculty of Arts and Humanities, University of Macau, China. \\
\hline Funding & No funding received. Published free of any charge. \\
\hline Article DOI & https://doi.org/10.21659/rupkatha.v14n1.04 Pages: 1-12 \\
\hline Abstract & https://rupkatha.com/v14n104 \\
\hline Full-text PDF & https://rupkatha.com/V14/n1/v14n104.pdf Ø \\
\hline \multirow[t]{3}{*}{ Article History } & Abstract received: 3 March 2021 | Complete article received: 19 June 2021 \\
\hline & Revised article received: 1 Sept 2021 | Accepted: 9 Sept 2021 \\
\hline & First Published: 05 February 2022 \\
\hline Article Impact & Check Dynamic Impact $\pi$ \\
\hline Copyright & Aesthetics Media Services $\oslash$ \\
\hline Licensing & Creative Commons Attribution Non-Commercial 4.0 \\
\hline
\end{tabular}

This Open Access article is published under a Creative Commons Attribution Non-Commercial 4.0 International License (http://creativecommons.org/licenses/by-nc/4.0/), which permits non-commercial re-use, distribution, and reproduction in any medium, provided the original work is properly cited. For citation use the DOI. For commercial re-use, please contact editor@rupkatha.com. 
1 Rupkatha Journal, Vol. 14, No. 1, 2022

Research Article

\title{
Foreignized Translation of Onomatopoeia in The Last Lover
}

\author{
Minhui Xu \& Tingting Chen \\ Faculty of Arts and Humanities, University of Macau, China.
}

\begin{abstract}
The onomatopoeia in literary works frequently provokes translation problems and no consensus has been reached by translators. This study aims to explore the translation of onomatopoeia between Chinese and English, two drastically different languages, with a case of the translation of Can Xue's novel The Last Lover by Annelise Finegan Wasmoen. A detailed textual analysis has detected three major translation strategies: italicized transliteration, italicized transliteration plus target equivalents, and italicized transliteration plus explanation, with the second one occupying a lion's share. All the strategies demonstrate obvious efforts of foreignizing the translated onomatopoeia and produce a strengthened foreign effect. The facts that The Last Lover won the Best Translated Book in 2015 and that the statistics suggest a positive readers' response show that onomatopoeia, non-arbitrary across languages, has its potential to be transferred successfully between languages and cultures. A foreignizing translation strategy makes it possible for the sound effects of the onomatopoeia of the original to be preserved and for the target readers to experience something foreign, while its acceptance suggests the increased tolerance for translated literary works in the target system.
\end{abstract}

Keywords: Translation of onomatopoeia; Can Xue; Foreignization.

\section{Introduction}

The concept of onomatopoeia overlaps with imitative words and echo words. Although the definition of onomatopoeia seems different and varied across languages, it is commonly regarded as words that imitate sounds. According to Oxford English Dictionary, onomatopoeia is the "formation of a word from a sound associated with what is named." In contrast to English scholars who concentrate more on the phonological formation and the sound symbolism (Huang, 2011, pp. 23-24) which conforms to the Oxford definition, Chinese scholars delve into the grammatical classes and meanings of onomatopoeia, together with its rhetorical effects. The classification of Chinese onomatopoeia resorts to different criteria, such as the object for imitation, the type of sound used, the structure of characters, and the number of syllables (J. E. Li, 2006, p. 49). However, probably due to Saussure's isolation of onomatopoeia from the arbitrariness of the sign, linguistic academia often shows less preference to onomatopoeia than to phonoasthetics, ideophonology, and phonosemantics (Moore, 2015, p. 318). The seemingly second-rate status of onomatopoeia (Azari \& Sharififar, 2017, p. 73) leads to limited research and indeterminacy in the field of English linguistics. 
Despite the academic controversies, a consensus is reached that English possesses a relatively smaller number of onomatopoetic words compared with other languages (Sugahara, 2011 , p. 1). The categorization of onomatopoeia ranges from Ullmann's primary and secondary onomatopoeia to Bredin's direct, associative, and exemplary onomatopoeia (Azari \& Sharififar, 2017, p. 74). Bredin (1996) also concedes the difficulty of defining onomatopoeia about the nature of the relationship and the "strict" or "narrow" kind of definition (p. 555). In Chinese, the definition is clear as the dictionary classifies unequivocally more than 200 common Chinese onomatopoeia (Huang, 2011, p. 11). The existing comparative studies between Chinese and English onomatopoeia reveal the dominance of grammatical classes of adverb or adjective in Chinese (Fu, 2001, p. 10) and that of verb or noun in English (Sugahara, 2011, p. 63).

The linguistic differences between languages pose translation problems when translating onomatopoetic sounds. Given the differences in grammatical classes, the shift of class is inevitable in the translation between Chinese and English. However, previous studies about the translation of onomatopoeia reached no consensus on translation strategies, and the decision falls upon the translator's individual choice and style (Casas-Tost, 2014, p. 53). The frequently used methods by various translators consist of reduction and substitution, as is discussed in a corpus study of Chinese-Spanish literature translation (Casas-Tost, 2014, p. 53), where only $16.7 \%$ of the original onomatopoeia are translated into target onomatopoeia, reducing the rest by substituting with other words or paraphrasing them. Another study by Azari \& Sharififar (2017) summarized five common methods of translating onomatopoeia, namely, using non-onomatopoetic words, using onomatopoetic words, paraphrasing, omission, and using loan words.

As for the translation of onomatopoeia between Chinese and English, most previous studies focused on theoretical discussions about language differences and translation difficulties (Wang, 2013; Fu, 2001), and few studies (J. J. Li, 2020) were dedicated to textual analysis, except, perhaps, the studies of the translation of onomatopoeia in the Chinese classic $A$ Dream of the Red Mansion 红楼梦. Huang (2011) analysed in-depth the features of onomatopoeia and the translation methods of the two English versions and concluded that onomatopoeia was emphasized in both translations, with methods including using target onomatopoeia, compensation, creation of new words, omission, and proactively using onomatopoeia to translate the original sound-related images (p. 126).

That being said, the present study attempts to explore the translation of onomatopoeia through textual analysis, taking as a case The Last Lover, a novel written by the contemporary Chinese writer Can Xue. The study adopts a definition of onomatopoeia using non-intuitive sources, which is different from previous studies where the glossaries of "onomatopoetic" words are intuitively chosen without standardized criteria or dictionary-based definition.

In 2015, the author Can Xue and the translator Annelise Finegan Wasmoen began to enter into the public eye by winning The Best Translated Book. Sponsored by Amazon, the Best Translated Book Award (BTBA) is the only book award that is translation-related in the USA. The jury of the award credits Can Xue's writing as "the most radical and uncompromising... pushing the novel form into bold new territory," and the translator "succeeds in crafting a powerful English voice for a writer of singular imagination and insight" (Three Percent, 2019). The translator's choice 
in this novel offered new methods and techniques and shed new light upon the translation of onomatopoeia.

In the sections followed, a discussion about the literary role of onomatopoeia and some special features in The Last Lover will be given, followed by a detailed description of three strategies employed by the translator Wasmoen, and a discussion about the reasons, effects, and reception of such translation strategies.

\section{Onomatopoeia in The Last Lover}

Modern Chinese Dictionary lists 225 cases of onomatopoeia, including the frequency used and the recurrence of sound with different characters (Yuan, 2007, p. 38), though there are more occasions of creative uses of onomatopoetic words since Chinese characters can be repeated in different ways. The rhetorical effects of onomatopoeia and its communicative, rhythmical, expressive, and impressive power are confessedly recognized in the Chinese language.

Based on Modern Chinese Dictionary and the previous studies of modern Chinese onomatopoeia (J. E. Li, 2006), we've identified 56 cases of onomatopoeia in The Last Lover. Excluding the repetitive occurrences, there still exist 30 entries of onomatopoetic words. The onomatopoeia with the highest frequency is "weng/嗡" and "pa/啪 "一the former with 11 frequencies and the latter with 9 frequencies. Although these onomatopoetic words are common words with high frequencies, they differ in terms of their formal features: some of these words are with quotation marks while others are not. Some onomatopoeias in the original text are commonly used and easy to understand for Chinese readers, such as the hissing of the snake, the flapping of the cloth against the wind, and the yapping of the dog. However, there are some other onomatopoeias found in The Last lover depicting, for instance, the sound of cats giving electric sparks, the sound of a person's speech scattered in the air, and the indistinguishable sound from rosebush cracking and crackling, all suggesting a unique feature of Can Xue's writing. The uniqueness leads to ambiguities brought by unconventional collocations. These ambiguities embedded in the writings of Can Xue (and other avant-garde writers) make trouble for translators, for even if target equivalents can be found, what the target equivalents could convey is still questionable when the original meaning is undetermined.

On the other hand, English onomatopoeia is difficult to be standardized and conceptualized. According to the Oxford English Dictionary, onomatopoeia is the "formation of a word from a sound associated with what is named." However, definitions of onomatopoeia in the academic circle are diverse and obscured. Sometimes, the concept of "onomatopoeia" overlaps with the creation of words (Moore, 2015, p. 310). It is frequently referred to as words imitating the sound, with emphasis on its expressiveness and sound effects (De la Rosa Regot, 2015; Casas-Tost, 2014). Another difficult task is the classification of onomatopoeia, with previous studies adopting a qualitative method by collecting and categorizing words with different criteria and across various registers, not to mention the fact that native speakers judge differently whether a word strikes them as a strong or weak onomatopoeia (Sugahara, 2011, pp. 2-7). All these make it challenging to construe an authorized and comprehensive classification between onomatopoetic words and non-onomatopoeic words in the English language. 
Given this complexity, this study embraces different sources: a comprehensive list from a website called "onomatopoeialist.com"1", a doctoral dissertation categorizing onomatopoeia in spoken and written English (Sugahara, 2011), and Longman Dictionary (Mayor, 2009) about the word's sound effects and an indication of its imitative or echoic origin. Although the broader sense of onomatopoeia can extend to the words indicating manner or action (Sugahara, 2011, p. 16), this study will only focus on sound effects and leave aside the action-related onomatopoeia. Therefore, we propose four criteria for the identification of onomatopoeia in the translation:

a. To agree with the dictionary meaning which indicates the word is used in describing sounds;

b. To have an imitative origin as is stated in a dictionary;

c. To have been proved by previous studies that it is non-intuitive and dictionarybased;

d. To be incorporated in the website resource "onomatopoeialist.com"

To be taken as a target onomatopoeic word, the English translation of the Chinese onomatopoeia needs to satisfy three out of the four criteria mentioned above. Among the 27 English words the translator used to translate the original sounds, twenty can be identified as target onomatopoeic equivalents.

\section{Translation of onomatopoeia in The Last Lover}

For all the 56 cases of onomatopoeic sounds in the original, the translator employs strategies of transliteration, italicization, target equivalents, and explanation to render them. Transliteration and italicization are neither recorded previously in the translation of Chinese literature nor are they sufficiently discussed in previous studies. Interestingly, no signs of omission or loan words or newly created words are discovered in the translation in question.

Three types of translation strategies are employed by Wasmoen, all involving transliteration and italicization but differing in the supportive parts, such as using target onomatopoeia simultaneously, giving explanatory words, or providing a context. To put it simply, the three translation strategies are italicized transliteration with context, with target equivalents, and with explanation respectively. Her employment of transliteration and italicization reveals distinctive features compared with other translators. The frequency of using these strategies can be seen in Figure 1 below.

${ }^{1}$ http://onomatopoeialist.com 


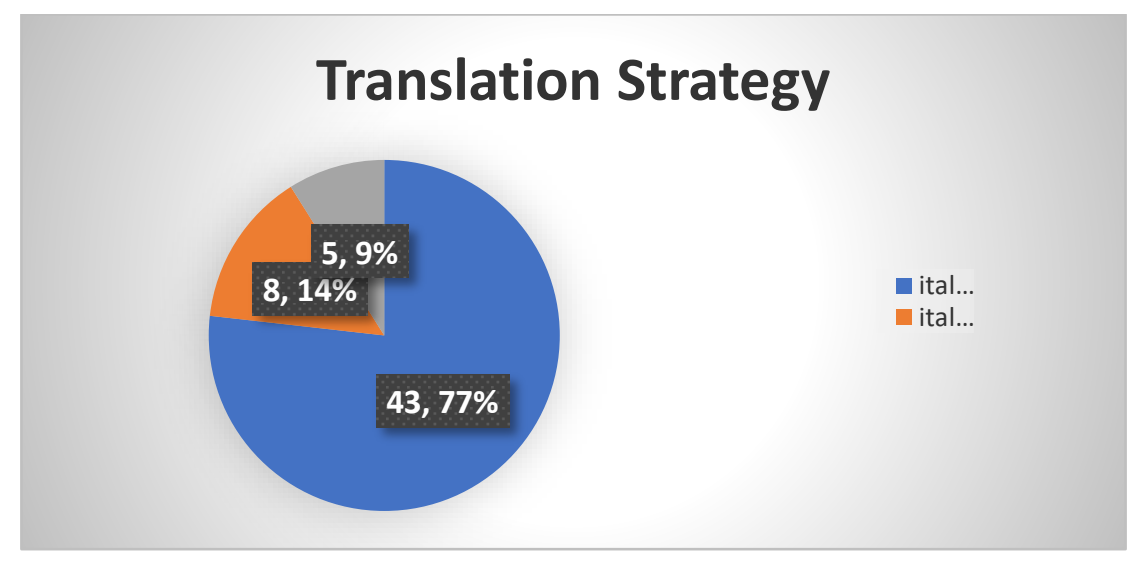

Figure 1: Translation Strategy

The most frequently used method is a combination of italicized transliteration plus target onomatopoeia, consisting of 43 cases and constituting $77 \%$. This is followed by italicized transliteration plus explanation, making up 14\%. The difference between these two categories lies in the fact of whether the target equivalents or the explanatory words are onomatopoetic words. As a conspicuous feature of the original is its richness in ambiguity, it hinders the preciseness of the target equivalent onomatopoeia. Wasmoen did not resort to omission despite the lack of suitable target equivalents. Instead, she resorts to extra explanation. The third strategy is italicized transliteration with context. It occupies $9 \%$ of all the cases. In this category, there are neither target equivalents nor explanations. The meaning is construed in the context. The following sections will give a detailed account of the features, the meanings, and the effects of these translations.

\section{a. Italicized transliteration with target onomatopoeia}

Using target equivalents is not a commonly-adopted method in the translation of onomatopoeia. Wasmoen, however, makes this strategy the most used one in her translation. Here is a revealing example:

\section{Example 1}

ST: 他听见了土地起伏的声音, “沙沙沙”的, 如一条巨蟒在前行。

TT: He'd heard the sound of the earth rising and falling, a sha sha sha rustling, like the movements of an enormous python.

In the original onomatopoeia, "sha sha sha/沙沙沙" is used to describe the sound of the moving earth, and the translation keeps the original sound of "sha sha sha" with a transliteration. The italicization serves to highlight the foreign source, and the target equivalent "rustling" helps to convey the meaning of the onomatopoeia of the rising earth.

When the same original onomatopoeia is used in different situations, the translator employs different target onomatopoeia to collocate with different words, helping readers understand the situated meanings:

Example 2

ST: 他听到他手里的书掉到了地上, “啪”地一声响。 
6 | Foreignized Translation of Onomatopoeia in The Last Lover

TT: He heard the book on his hand dropping to the floor with a thwack, pa.

Example 3

ST: ...有布匹发出“啪啪”的响声

TT: ...a cloth flapping with a pa pa sound

The "pa" in the first example indicates the sound of the book dropping onto the floor, while the "pa pa" in the second refers to the clothes flapping in the wind. The translator uses "thwack" for the description of the sudden hit between something flat, and "flapping" for a common onomatopoeic sound for pieces of cloth fluttering in the wind.

The translator also tries to make it consistent for translating similar onomatopoeia, so "zhiya/吱呀" and "zhizhi yaya/吱吱呀呀" are consistently translated into "creak," and "tong/嗵" and "tong tong tong/嗵嗵嗵" into "thump." Even for "susu/籁籁" and "shasha/沙沙," though these two onomatopoeiae are pronounced differently in Chinese, they share similarities both in sound and meaning. They are rendered into the same target onomatopoeia "rustle" because of a gap between the two languages. The 24 original Chinese onomatopoetic sounds with various combinations produce a richer source of onomatopoeia compared with the lack of sufficient English imitative words for sounds, 20 altogether. Wasmoen, however, manages to use 20 words to translate the 24 original Chinese onomatopoeias plus their variants, reaching a close match with the original.

\section{b. Italicized transliteration with explanation}

The second strategy is italicized transliteration with explanation due to the lack of target equivalents, making up $14 \%$ of all the cases. These explanatory words are not onomatopoeia based on a non-intuitive categorization. Details are shown in Table 1 below:

\begin{tabular}{|l|l|}
\hline ST & TT \\
\hline 1.周围有东西在“喳、喳、喳! “地响 & ...things whispering, cha cha cha \\
\hline 2.口里发出“啧啧”的赞美声 & $\begin{array}{l}\text { They merely made a ze ze tongue-clicking } \\
\text { sounds of admiration }\end{array}$ \\
\hline 3.雪在他的脚底下喳喳地响 & $\begin{array}{l}\text { The snow under his shoes made a cha cha } \\
\text { whisper... }\end{array}$ \\
\hline 4.当他“嗡嗡”地发声之际 & ...at the weng weng droning of his speech \\
\hline 5.太阳光也发出嗡嗡的声音 & The sunlight made a weng weng drone \\
\hline 6.非洲猫。。。发出“啪啪”的响声 & $\begin{array}{l}\text { One of the African cats ....making pa pa } \\
\text { crackling noises... }\end{array}$ \\
\hline 7.粽漽的泉水流进一口野井 & $\begin{array}{l}\text { The babbling spring, chan chan, run down } \\
\text { into a natural well... }\end{array}$ \\
\hline 8.他的声音从胡子里头嗡嗡地透出来 & $\begin{array}{l}\text { His voice came through his beard with a } \\
\text { weng weng droning }\end{array}$ \\
\hline
\end{tabular}

Table 1 Italicized transliteration with explanation 
The reasons for adopting an explanatory word rather than a target onomatopoetic word result from the original ambiguity and the lack of target equivalents. When translating the sound made by the snow under human's footsteps (example 3 in Table 1) and the sound made by the surrounding anonymous objects (example 1 in Table 1), the original "cha cha/喍喳" is an onomatopoetic word used to indicate the chattering and whispering in low voice and to describe the chirping of birds. However, to explain the sound of snow and of indistinguishable sources, "whisper" makes a suitable explanatory word to reduce the effort of reading "cha cha" or "cha cha cha" without much interpretation of the original. In this case, readers can experience a foreign onomatopoeic sound "cha cha" but also understand the whispering sound made by surrounding objects and by the contact between snow and the shoes.

There are linguistic barriers to locating the target equivalents. The original "ze ze/啧啧" (example 2 in Table 1) in Chinese not only mimics the sound of clicking the tongue but also is commonly used to show admiration. It is difficult to find a suitable English onomatopoetic word to re-present both the original sound effect and the associated meaning. However, the translator resorts to transliteration with explanation to keep the sound and explains the meaning-generating activity, the "tongue-clicking sounds." While the association between tongue-clicking and admiration in the target system may not be as natural as that in the original, the translation maintains a certain degree of readability and preserves an alien effect.

\section{c. Italicized transliteration with context}

The third strategy accounts for the most foreignizing effect in the translation because there are neither target equivalents nor explanatory words to help readers understand the onomatopoeia. The meaning of the italicized transliteration is construed in the context, as is shown in Table 2 below:

\begin{tabular}{|l|l|}
\hline ST & TT \\
\hline 1. 金“嘿嘿”地笑着 & Kim laughed, hei hei \\
\hline $\begin{array}{l}\text { 2. 她正在摆弄那些石头, 发出 “哗华” } \\
\text { 的响声 }\end{array}$ & $\begin{array}{l}\text { Grandma was playing with the pebbles. } \\
\text { They made a hua hua sound }\end{array}$ \\
\hline $\begin{array}{l}\text { 3. 那两只猫从她身边跑过去, 身上也 } \\
\text { 在啪啪地放电。 }\end{array}$ & $\begin{array}{l}\text { The two cats ran over from behind her, } \\
\text { their bodies giving off electric sparks, } \\
\text { pa pa }\end{array}$ \\
\hline 4. 他跌倒时发出“砰”的一声闷响 & He tumbled with a muffled peng \\
\hline 5. 马丽亚“扑哧“笑出了声 & Maria snickered, pu chi, saying... \\
\hline
\end{tabular}

Table 2 Italicized transliteration with context

As is illustrated in the table, the transliteration "hua hua" (example 2 in Table 2) is used to describe the sound made by playing with pebbles. There is no explanation about what kind of sound the pebbles make, be it gurgling or clanking. "They made a hua hua sound," the italicized transliteration with context for readers to contextualize that "hua hua" would be the sound made 
by pebbles. Similarly, in examples 3 and 4, "pa pa" would be the sound of cats' bodies giving electric sparks, and "peng" would be the muffled sound when someone tumbles.

If these italicized transliterations were removed, the translated texts are grammatically correct. Wasmoen wants to stress the transliterated sounds to enable an exotic sound effect and to make readers understand the flavor of the original enigmatic writing style.

Wasmoen's translation also shows defiance of rather than conformity with the target linguistic rules. The original sound "puchi/f卜哧" (example 5 in Table 2) is maintained without any changes except that the quotation marks are removed, and the words are in italicization. Not like the translations of $A$ Dream of the Red Mansion (红楼梦) where the same word is rendered into target equivalents of "chuckle," "giggle," "titter," and "splutter", or created new words in conformity with English rules such as "chee-e-e," Wasmoen's translation requires readers to understand the exotic "puchl" in the context.

Of the 56 cases of the original onomatopoetic words, all original sounds are transliterated with italicization, a strong indication of foreignness, yet $77 \%$ of them are translated with target onomatopoeia to ease the reading anxiety. However, when there are linguistic barriers or difficulties in locating target onomatopoetic sounds, $14 \%$ of the cases are italicized and transliterated with explanatory words for the sake of readability. The remaining $9 \%$ of the cases are also transliterated and italicized, though there is only context to help readers construe the connection between the sound and the meaning.

Another point worth mentioning is that Wasmoen treats the same original onomatopoetic sound with different translating methods to diversify the sound effects and to obtain readability. While maintaining a certain degree of readability by using supportive target onomatopoeia and explanatory words, the italicization and transliteration in Wasmoen's translation showcase the deviation from the target linguistic norms and the consistent effort to produce a foreignized text.

\section{Discussion}

Wasmoen's translation of onomatopoeia presents a case of foreignization with all onomatopoetic words transliterated and italicized. The reason for such a foreignizing effort lies first in the translator herself. Wasmoen is fully aware of the linguistic potential in Can Xue's writing where the form might be more important than the meaning, as linguistic boundaries have been broken by unconventional usage commonly seen in avant-garde writings. Wasmoen said in an interview with Can Xue that she constantly felt "freedom and openness" (Wasmoen, 2015) of Can Xue's writing during her translation since Can Xue's choice of words and phrases are free and open to indeterminacy. When dealing with the ambiguity of the original onomatopoeia, Wasmoen treats it carefully and chooses different methods to render it.

Wasmoen's literary background enables her to be more aware of the linguistic potential of the literary features such as those demonstrated in the onomatopoeia. Wasmoen was trained in comparative literature, and she participated in an Interuniversity Program of Chinese language and literature in Beijing, which equipped her with a stronger sense of literariness when rendering many details of the original - the onomatopoetic words, sound effects, quotation marks, etc. - 
important elements to be retained in the target text. Therefore, the onomatopoetic sounds, together with the quotation marks of the original, are consistently italicized in the target text. No omission of the striking features of the original has been detected.

In comparison with other translations of Can Xue's works, the adherence to the original and the degree of foreignization are amplified and heightened in The Last Lover. Wasmoen's translation keeps every single paragraph in the source text corresponding with those of the target text, even to the degree that the page numbers between ST and TT are rendered to match each other to easily locate the source and the target when doing a textual comparison.

The relationship between the author and the translator also accounts for the foreignization strategy. The Author-translator relationship is varied from one to another. Different combinations of author-translator can have a highly distinctive style of collaboration and result in different translation products. The author-translator relationship has a considerable impact on the translation strategy. Can Xue and Wasmoen's relationship present an intriguing case. First of all, Can Xue understands English, reads English literature, and even translates English texts into Chinese (Can Xue, 2007, p. 11 \& p. 74). She has the power to interfere with the translation. In Wasmoen's account, Can Xue was deeply involved in the translation process. They have corresponded with each other for five years, during which they exchanged opinions and shared drafts of translation (Wasmoen, 2015). Hence, the foreignized translation may be influenced by the original author's opinions and suggestions.

Secondly, Can Xue has been quite critical with her translators: misinterpretation of her work would result in the termination of their collaboration. Once there were no suitable translators, she ceased all translation activities and waited for the "right" translator for seven years (Cen, 2018, p. 118). She claimed that all Wasmoen's translations had to be examined and approved by her (Zhuo, 2013). It might be a remark for a joke, but the undeniable fact is that Can Xue indeed can check and examine the translation to see if there was any misinterpretation or misunderstanding.

Besides, Can Xue has been actively engaged in western cultural society, maintaining close relationships with publishers and friends from literary circles (Cen, 2018) and participating in cultural activities. She went to visit American universities, watch theatre performances in New York Metropolitan Opera House (Liu, 2017, p.191), and attend conferences and literary seminars and writers' workshops (Khakpour, 2014). She has accumulated enough cultural capital to exert some control over the translation. Before collaborating with Wasmoen, Can Xue was already a worldrenowned literary figure with many works translated into several languages around the world.

Wasmoen, however, had not translated any novel-length literary works before Can Xue. The opportunity to translate Can Xue's novel has to be earned. Wasmoen talked about her story about earning the opportunity to translate Can Xue's novels. It was more of "leaping at the opportunity" than "being led to translate" (Three Percent, 2021). She introduced herself to Can Xue, offering her translation of a part of the novel. After being approved by Can Xue who acknowledged her linguistic competence, she became Can Xue's fifth translator.

There exists an imbalanced power relationship between the translator and the author. Therefore, the loyalty to and the respect for the author and the original text lead to a more source- 
text-oriented translation, where the original features are expected to be maintained, leading to her general translation strategy of foreignization with close adherence to the original.

\section{Conclusion}

The analysis of the translation strategies employed by Wasmoen for Can Xue's avant-garde novel The Last Lover (最后的情人), reveals that $77 \%$ of the onomatopoeia are translated with italicized transliteration plus target onomatopoeia, significantly higher than that (16.7\%) revealed by the comprehensive corpus study of Chinese to Spanish translation of contemporary Chinese novelists, demonstrating the translator's seriousness towards the original onomatopoeia. It also suggests a feature distinctive from other translations which use substitution or reduction or omission to avoid the difficulty of translating onomatopoeia. Wasmoen orients towards more literary and scholastic appreciation of the original text, featuring the onomatopoeia as it is in the original, resulting in a strongly foreignized translation of all onomatopoetic sounds.

The foreign effect of transliterated onomatopoetic sounds does not hinder the readability as readers notice the exotic features brought by italicization and transliteration which bring out an alien reading experience. Readers are defamiliarized, challenged, perplexed, and intrigued. The uncompromising author and the unwavering translator successfully delivered a difficult but interesting reading for target readers to experience dreamlike irrational surrealism with the help of exotic sound effects.

\section{Declaration of Conflict of Interests}

The author(s) declared no potential conflicts of interest.

\section{Funding}

No funding has been received for the publication of this article. It is published free of any charge.

\section{References}

Azari, R., \& Sharififar, M. (2017). Translating onomatopoeia: An attempt toward translation strategies. Review of Applied Linguistics Research, 3(3), 72-92.

Bredin, H. (1996). Onomatopoeia as a figure and a linguistic principle. New Literary History, 27(3), 555-569.

Can Xue (2014). The Last Lover. (Anna Finegan Wasmoen trans). New Haven \& London: Yale University. (Original work published 2005).

Can Xue (2005).最后的情人 [The Last Lover]. Guangzhou: Huacheng Publishing House.

Can Xue (2007). 残雪文学观 [The literary view of Can Xue]. Guilin: Guangxi Normal University Press.

Casas-Tost, H. (2014). Translating onomatopoeia from Chinese into Spanish: a corpus-based analysis. Perspectives, 22(1), 39-55. 10.1080/0907676X.2012.712144. 
Cen, Q. X. (2018). 残雪介入 《最后的情人》英译与接受的社会学探析 [The sociological analysis of Can Xue's interference in English translation and acceptance of The Last Lover]. Shandong Foreign Languages Teaching, (03), 115-122.

De la Rosa Regot, N. (2015). Translating Sounds: The Translation of Onomatopoeia between English and Spanish. [End-of-Degree Paper, Universitat de Barcelona].

Fu, J. M. (2001). 思维视角的英汉拟声词研究及其翻译 [A Thinking perspective study on Chinese and English echoic words and their mutual translation]. Shanghai Journal for Translators for Science and Technology, (4), 7-11. 10.3969/j.issn.1672-9358.2001.04.002.

Huang, S.T. (2011). 《红楼梦》拟声词及其英译研究 [A Study of Onomatopoeia and its Translation in Hongloumeng]. [Doctoral dissertation, Shanghai International Studies University]. CNKI.

Khakpour, P. (2014). Porochista Khakpour on Can Xue. LITERARY MOTHERS. Retrieved April 42019 from https://literarymothers-blog.tumblr.com/post/85424855047/porochista-khakpour-on-can-xue

Li, J. E. (2006). 现代汉语拟声词研究 [Onomatopoeias in Modern Chinese]. [Doctoral dissertation, Fudan University]. CNKI.

Li, J. J. (2020).《活着》白译本中拟声词的翻译研究 [A study on Michael Berry's translation of To Live: a novel. Journal of Kaifeng Vocational College of Culture \& Art, 40(07), 52-53. 10.3969/j.issn.20967853.2020.07.024.

Liu, K. (2017). 西方读者视野中的残雪[Can Xue in western readers' horizon]. Journal of Social Science, (5), 185-191.

Mayor, M. (Ed.). (2009). Longman dictionary of contemporary English. Pearson Education India.

Moore, C. (2015). An ideological history of the English term onomatopoeia. Studies in the History of the English Language VI: Evidence and Method in Histories of English, 307-320.

Onomatopoeia. (n.d.). In Oxford Dictionaries Online. Retrieved March 18, 2021, from http://www.oxforddictionaries.com/definition/english/onomatopoeia.

Sugahara, T. (2011). Onomatopoeia in Spoken and Written English: Corpus-and usage-based analysis. [Doctoral dissertation, Hokkaido University].

BTBA 2015 Winners: Can Xue and Rocío Cerón!. (n.d.). Three Percent. Retrieved 7 December 2019 from http://www.rochester.edu/College/translation/threepercent/2015/05/27/btba-2015-winners-canxue-and-rocio-ceron/.

Why This Book Should Win: Q\&A with Annelise Finegan Wasmoen about The Last Lover. (n.d.). Three Percent. Retrieved 20 September 2021 from http://www.rochester.edu/College/translation/threepercent/2015/04/27/why-this-book-shouldwin-qa-with-annelise-finegan-wasmoen-about-the-last-lover/.

Wang, K. (2013). 翻译与阅读的政治——漫议“西方”、“现代”与中国当代文学批评体系的调整 [A political aspect on translation and reading - discussion on western, modern, and the systematic adjustment of criticism on Chinese contemporary literature. Literary Review (6): 98-108.

Wasmoen, A. (2015). Can Xue by Annelise Finegan Wasmoen. BOMB magazine. Retrieved May 13, 2019 from https://bombmagazine.org/articles/can-xue/.

Yuan, M. J. (2007). 《现代汉语词典》里的拟声词 [Onomatopoeia in Modern Chinese Dictionary]. Linguistic Research, (1), 38-41. 
Zhuo, J. (2013). 关于“新努斯的大自然"--残雪访谈录[An interview with Can Xue - about New Nous in nature]. Creation and Criticism, (3), 11-23.

Minhui $\mathrm{Xu}$ is an Associate Professor at the University of Macau. She holds a PhD in Translation Studies. She is the author of English Translations of Shen Congwen's Stories - A Narrative Perspective and has published in refereed journals both in English and in Chinese, including Target: International Journal of Translation Studies, Perspectives: Studies in Translation Theory and Practice, Translation and Interpreting Studies and China Translators' Journal. Her main research area is translation studies, focusing on translation theory, translation history, literary translation, sociology of translation, and translation and intercultural studies.

Tingting Chen is a MA student of Translation at the University of Macau. 